\title{
Benefits of Agroforestry on Smallholder Farms in Jigawa State, Nigeria
}

\author{
Attia M. El-Tantawi ${ }^{1}$ Aziza M. Badr ${ }^{2}$ and Umar S. Daura ${ }^{3}$ \\ ${ }^{1}$ Prof. of physical Geography, Institute of African Research and Studies, Cairo University, Egypt \\ ${ }^{2}$ Prof. of Human Geography, Institute of African Research and Studies, Cairo University, Egypt \\ ${ }^{3}$ Lecturer of physical Geography, Umaru Musa Yar'adua University-Katsina, Nigeria
}

\begin{abstract}
With about $80 \%$ of people in Jigawa involved in agriculture, it is safe to say agriculture lies at the heart of the economy in the state. However, a combination of crude implements, inadequate artificial fertilizers, all add to the tedious environmental setting in which farming is carried out. This study attempts to show how agroforestry practice yields much needed benefits in the study area. The study used multistage sampling; three zones in the state, Jigawa northwest, Jigawa northeast and Jigawa south. Out of each zone, 3 Local Government LGA were selected, out of which 50 respondents were purposively targeted from each community making an overall total 450 respondents. Descriptive statistics using mean, percentages and use of table and figures were used for the analysis. The results show that the benefits derived by the respondents are fertility maintenance $83 \%$, fodder for livestock $81 \%$, Micro-climate has moderation 66\%. Increasingly as in other parts northern Nigeria, results show a number of tree species noted for their medicinal value are becoming extinct due to the pressures of demand both in forests and on farms. The study recommends boosting further research to conserve these disappearing species from extinction.
\end{abstract}

Keywords: Agroforestry, Smallholder farms, Fuel-wood, Carbon sequestration

\section{Introduction}

Attaining Food security and tackling environmental degradation are two formidable encounters threatening humanity (Ekwugha 2016, p.12). To achieve this, a sustainable method of protecting and strengthening our agricultural system needs to be put in place.The need for this sustainable technique is ever critical to the ecosystem of marginal lands of the semi-arid area in which Jigawa state lies in. A need for a strategy that can ensure the

resource poor farmer maintains the benefits he derives from the farmland in a setting where artificial fertilizers are virtually beyond his reach becomes imperative.

Agroforestry has been defined in many ways over the last three decades; it started gaining more attention by researchers. Gold and Garrett (2009) looked at agroforestry being an intensive land management practice in which trees and/or shrubs are deliberately incorporated with crops in an agricultural setting. ICRAF defined it as a "collective term for a land use systems and practices whereby woody perennials are intentionally integrated with crops and/or animals on the same land management unit (ICRAF, 2004). Leakey (1996) faulted the definition saying that it fails to take cognizance of ultimate potential of agroforestry as a way of mitigating deforestation. Thus, he opined that agroforestry to be a dynamic, ecologically based, and natural resource management system. A system in which socio-economic and environmental benefits in smallholder farmswas diversified and sustained, all this was done through the integration of trees on farms and on rangelands (Leakey1996).Wireko (2011) highlighted that the practice of agroforestry is accompanied with several benefits. The benefits are both economic as income generation and environmental such as decreased run off and increasing infiltration rates amongst others.

Depending on the type of environment and soil type of the particular farm plot, different tree-crops combination were used to get the optimum returns from the land (Nawaz, et al., 2016). Areas in close proximity to protected areas can experience improvement in biodiversity and reduce the rate or restore degraded land altogether, thus aiding conservation of biodiversity (Nair et al., 2005, andBaghwat et al,2008)).

ICRAF (2004) further asserted that in cases where land is limited and susceptible to erosion, the practice offers viable benefits over long-term agricultural sustainability. It can be used as a tool that that simultaneously reverses environmental degradation and at same time maintain sustainable agriculture to the rural poor (UNCCD2003).There are also several situations, which tend to militate against the adoption of the practice. 
Against this backdrop, this study looked at the benefits that are obtainable on the smallholder farms in Jigawa state, northern Nigeria.

\section{The study area}

JigawaState is a relatively young state. It wascreated in 1991 fromtheformerKanoState is situated in the northwestern region of Nigeria. TheStateisboundedtothenorthbythe NigerRepublic,to east by Bauchi and YobeState,southbyKanoStateandtothewest by KatsinaState(Figure 1).It lieswithinlatitudes $11.00^{\circ} \mathrm{N}$ to $13.00^{\circ} \mathrm{N}$ and longitudes $8.00^{\circ} \mathrm{E}$ to $10^{\circ} .15^{\prime} \mathrm{E}$. It covers an estimated area of $23,154 \mathrm{~km}^{2}$ (8,940 sq. miles).Geologically, basement complex underlie the northwestern part of Jigawa, while intrusions of younger granites are in southern parts of the state,sedimentary Chad Formation underlies the eastern part of the state(Olofin, 1997, p.17).

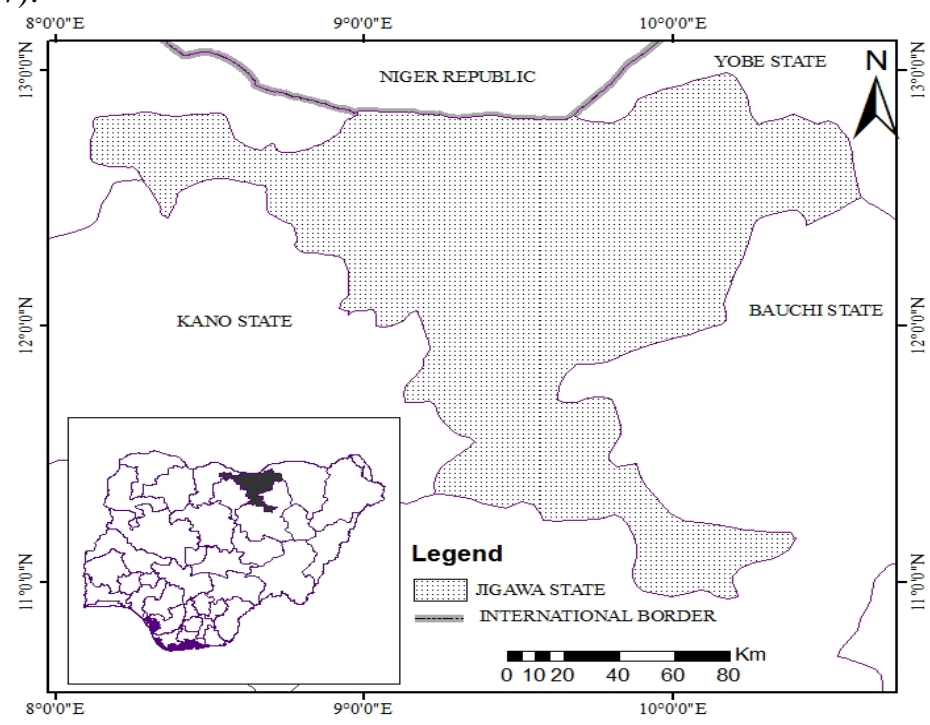

Figure 1: location of Jigawa State

As for climate, the area is located and categorized in hot-dry semi-arid climate with hot season and cold dry season. The mean annual rainfall of the area is about $800 \mathrm{~mm}$ and evapotranspiration 1600 (Abu-Bakr et al., 2010). A study by Olofin and Tanko (2002) also indicated that, the region is characterized by low rainfall (850$870 \mathrm{~mm}$ ) and high rainfall of about $4200 \mathrm{~mm}$ in a wettest year. The region is also characterized by high evaporation in the hottest months (Dakata and Yelwa, 2012). Vegetation in the state is sparse bushes, open grassland and few natural forests. The trees are made of variety of species like Faidherbia albida, Acacia seyal, Parkia biglobosa, and Anogeissus leiocarpus. Presence of long taproot and leathery leaves enables these trees to adapt to drought conditions (Dakata et al 2012). Location of the State at a point where the high plains of Hausa characterized by the basement complex formation slopes gently crosses the hydrogeological divide toward the chad formation. This enhance the presence of diverse trees and shrubs, with quite a number having edible seeds and fruits, the leaves as fodder, the fiber and trunks as firewood, others medicinal importance. The area is mainly agrarian (agriculturally dependent), and it is divided into three Geo-administrative zones, each of which is composed of several local government administrative areas.

The National population commission 2006 census recorded the population of the state at 4.3 million (NPC, 2010). The State is made up of 27 local government areas with over 300 towns, villages and other settlements. The people of the state are mainly and farmer's traders, other occupations include blacksmithing, leatherwork, calabash carving and mat weaving.

\section{Material And Methods}

A random sample selection was used in sampling three local governments from each of the three geoadministrative zones (senatorial districts) in the study area. Three farming settlements were then purposively selected in each LGA, employing sampling technique to make a sum total of nine. In each of the three sampled farming communities, a purposive sampling was employed in selecting fifty respondents and semi-structured questionnaire was administered on them. A total number of 450 farmers were sampled to make up the total respondents for the study. The use of simple descriptive statistics was employed in analyzing data collected. These include percentages, frequency distribution, Tables, and charts. The responses on benefits were tabulated and the use of bar charts used to depict all the benefits of agroforestry on smallholder farms in Jigawa State. 


\section{i. Benefits of Agroforestry}

\section{Results And Dicussions}

The gains a farmer receives from the practice of agroforestry can be term as the benefits. The benefits are basically 2 fold, namely economic and ecologically. Enhancement of soil fertility maintenance through nitrogen fixation via rooting system or litter fall, consolidation of soil by organic matter thereby checking erosion are ecological benefits. On the other hand, provision of fodder (animal feed), and in some cases fuelwood are economic benefits. Babalola (2009, p. 26), postulated nature has its checks and balances through which it regulates the environment. He states that cycles like the nitrogen and water cycle help to maintain ecological balance. He further affirms that agroforestry has the propensity to facilitate soil renewal. According to Charley and West (1977, p . ), Nitrogen N, Phosphorus P are the rate limiting elements in soil fertility refurbishment. Trees and shrubs on farms help with this process. Richard et al, (2009, p. 105), buttress the point saying environmental stability and other benefits like income generation of agro-forestry to the resource poor farmers, makes it more appealing to them(farmers). Multiple benefits are derived from trees as sighted (Verheij, 2003, p.13). Trees he argued provide to the soil, protective cover from accelerated erosion through reduction of velocity of runoff and increase in infiltration rate. Modifying of microclimate through sheltering crops in the field from heavy draught. Trees yield suitable niche for the nesting of various species of aves(birds) support to companion crops on the farm. Although agroforestry is saddled with the ability to offer the farmer several benefits, it must be recognized that the benefits derived are dependent on the site. They vary across the various ecological zones within the Nigeria and the continent as a whole.

Table1: Benefits of Agroforestry

\begin{tabular}{|l|l|l|l|l|l|l|l|}
\hline \multirow{2}{*}{ Benefits } & \multicolumn{2}{l|}{ Jigawa northwest } & \multicolumn{2}{l|}{ Jigawa northeast } & \multicolumn{2}{l|}{ Jigawa southwest } & \multicolumn{2}{l|}{ Total } \\
\cline { 2 - 8 } & NO. & $(\%)$ & NO. & $\%$ & NO. & $\%$ & $\%$ \\
\hline Increase Soil Fertility & 134 & 89 & 117 & 78 & 128 & 85 & 83 \\
\hline Erosion Control & 131 & 87 & 114 & 76 & 111 & 74 & 79 \\
\hline Fodder for livestock & 129 & 86 & 134 & 89 & 98 & 65 & 81 \\
\hline Food and medicine & 123 & 82 & 141 & 94 & 123 & 82 & 86 \\
\hline Fuelwood Source & 132 & 88 & 122 & 81 & 135 & 90 & 86 \\
\hline Micro climate & 104 & 69 & 92 & 61 & 98 & 65 & 66 \\
\hline
\end{tabular}

Source $2015 *$ multiple responses shows percentages to be more than 100

The study area lies almost entirely within the Sudan savannah zone except for the southern tip of the state, which has the semblance of the northern Guinea savannah. Some of the benefits they (farmers) attribute to agroforestry in the study area are several and they include; fertility maintenance, fodder for livestock, fuelwood.

\section{ii. Fertility of Maintenance (Increase in soil fertility)}

Table 1 shows data on the respondents' views on farmers gains in the study area. A careful look at table 10 indicates that $83 \%$ of the total respondent farmers are of the opinion that certain tree types such as Faidherbia albida (Winter thorn) tree, Parkia species help enhance fertility of the soil through nitrogen fixation by trees on the farm. Scientifically this by (Zacharia,1997 p. 34) attest to this assertion of Faidherbia albida (Winter thorn) tree help fertility status. The table further reveals that Jigawa northeast has $78 \%$ of the farmers in and Jigawa Northwest $89 \%$ of the farmers and finally Jigawa southwest has lesser numbers with $85 \%$. The implication could be rejuvenation of fertility status on farms by Nitrogen-Fixing Trees. Suffice to say that, resource poor farmers is given a relatively cheaper alternative where there is insufficient availability of artificial fertilizer in his quest to attain food security. In southwestern part of the study area especially around Dutsearea, trees such as Phoenix dactylifera (Date palm), Tamarindus indica (Tamarind tree) have the unique ability to survive comfortably in alkali soils with high amount of soluble salts. They can withstand a $\mathrm{pH}$ value of up to 8.0 .

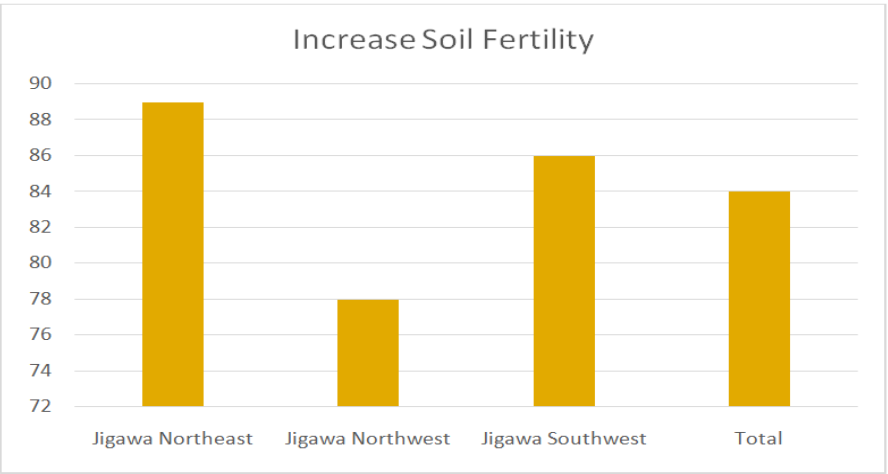

Figure 2: Benefit from soil fertility maintenance 
Figure 2 shows the responses received from the farmers within the study area of Jigawa state. It shows that an overall total of $83 \%$ see that agroforestry help maintain soil fertility of farms to a certain degree.

\section{iii. Microclimate}

The contemporary issue of climate change coupled with ever-increasing expansion is placing a heavy burden on food security. This combine to put the smallholder farmer under increasing threat of environmental degradation. To relieve this condition, Sobola et al (2015) argued the case that increase carbon dioxide levels can be reduced through adoption of $\mathrm{CO} 2$ (carbon dioxide) reduction mechanisms. He stresses that agroforestry, is a land use that incorporates trees and/or shrubs with food and fruit crops has the propensity for the sequestration of Carbon. ${ }^{4}$

Another assertion by Mbow et al $(2014$, p.9) recommends in the same line is a cautious use of shrubs and trees on farmlands and in forests to mitigate Climate change. He emphatically cautions that due to poverty, the priority of the farmer is income generation and not carbon sequestration. The farmer will not risk using his very small farm plot just to partake in a scheme to sequesteration of carbon. Thus, it is safe to say any option offered to the farmer to the farmer may fall very short if it does not assure him the gains he gets form each cropping season.

Table 1 show the benefits that the farmers in the study area in terms of modifying effect of trees on microclimate. The table reveals $66 \%$ of the respondents are of the opinion that they derive benefit though the practice. There was a higher percentage response with $69 \%$ in Jigawa northeast where there are large numbers of farmlands that are in close proximity with shelterbelts. This is particularly evident in Yankwashi local government area. Jigawa northeast has $62 \%$ while Jigawa southwest has $65 \%$.the farmers asserted that these help protect their plants from strong winds both during early growth and during flowering. The figures 2 shows a summary of the microclimate responses and percentage of the farmers revealing six benefits from agroforestry in the area respectively.

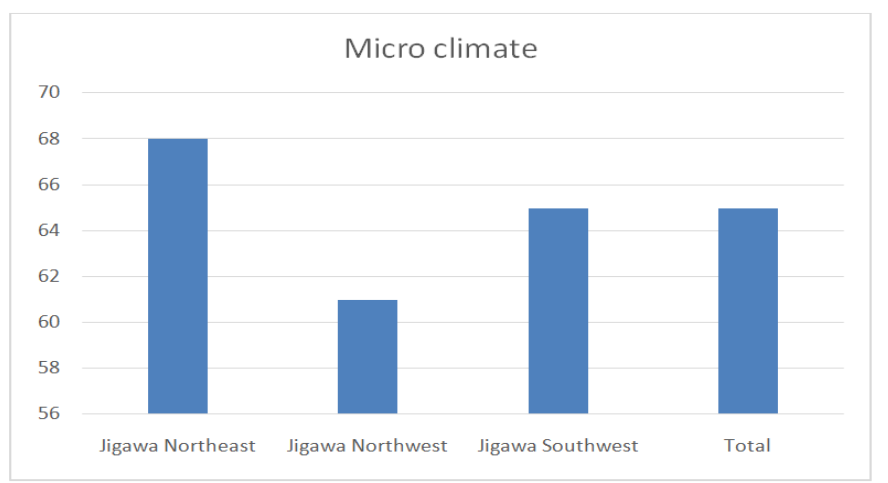

Figure 3: Responses on benefits Microclimate in the area

\section{iv. Fodder For Livestock}

Fodder in agricultural term for animal feed, and fodder trees and shrubs are those plants (shoots or sprouts, especially tender twigs and stems of woody plants with their leaves, flowers, fruits or pods) that are raised, used and managed to feed livestock(Jamala et al, p . 11). Fodder plants are plants which are grown in order to provide the nutritional needs of animals. Babayemi and Bamikole, (2006) opined that fodder and shrubs are important components of ruminant diet and they have been found to play an important roles in the nutrition of grazing animals in areas where few or no alternatives are available. Inadequate feed supply is an obstacle in maintaining livestock during the dry season in the savannah. As a major source of animal feeds in Africa, fodder trees and shrubs are highly valued by farmers. Browses have multiple roles in farming systems such as feed, fuel wood and as human and veterinary medicines (Luseba and Van der Merwe 2006). The most common fodder tree plant kept on the farms by the farmers in the study area are the Parkia species. This is leguminous a trees that has an extensive root system which enables it to extract soil and water from deep layers thus minimizing plant -crop nutrient competition. In the Sudan savannah crops like groundnut, cowpea, grow under Parkia clappertonia (Ogunbosoye et al., 2010, p. 2721). The trees have reasonable amount of nutrients in their seeds and pods. The seeds contain between $25-30 \%$ crude protein, $20 \%$ fatty acids $3.8 \%$ crude fibre and $5.3 \%$ oils. Table 1 presents data on the benefits of fodder to respondents in the study area.It can be seen from the table 1 that $86 \%$ Jigawa northwest derive benefits as fodder and $89 \%$ from Jigawa northeast with the highest of the

\footnotetext{
${ }^{4}$ Carbon Sequestration: Is the process of carbon capture and the long-term storage of atmospheric carbon dioxide $\left(\mathrm{CO}_{2}\right)$ both above ground and below ground to mitigate global warming.
} 
respondents. The lowest percentage is that seen in Jigawa Southwest (65\%). In Jigawa northwest in Babura L.G.A, findings show widespread distribution of the apple thorn tree (Faidherbia albida) on farms. The high density of this nitrogen -fixing trees after inquiry from the farmers, shows that they do not voluntarily and deliberately plant these trees but when they sprout on their farms they tend to care and maintain them. Figure summarizes the data on the benefits of fodder to farmers in the study area.

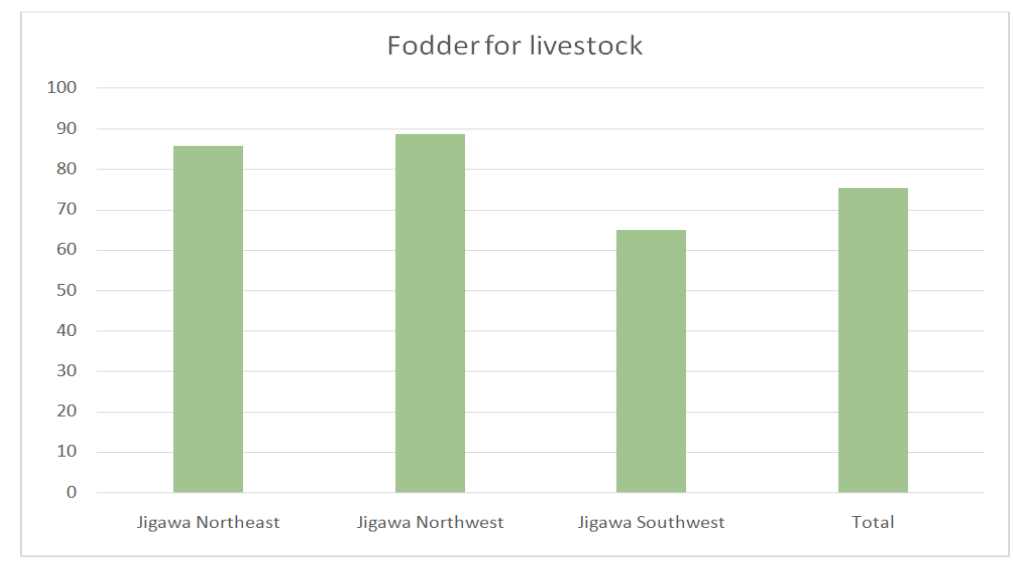

Figure 4: Benefits of fodder to farmers in the study area.

Figure 4 shows the graphical representation of the distribution of benefits over the various zones of the study area. About $76 \%$ of the total respondents reveal that they benefit from use of fodder trees/shrubs on the farms.

\section{V.Fuelwood:}

Fuelwood is a renewable form of energy that has continued to be the only energy option (especially for cooking) for most people in northern Nigeria. Results from recent studies of the Nigerian fuelwood situation suggest that the majority of the population has reverted to the use of fuelwood in recent times. This assertion comes in a study conducted in Kano city in Northern Nigeria (Maconachie et al., 2009. P. 1).

Fuelwood consumption in Nigeria like in other sub Saharan Africa is very high. This is a result of absence of viable option. The energy stored in fuelwood is measured in thousand metric tons of oil equivalent (TOE) - (1 metric TOE is defined as 41.868 Gigajoules which is equal to the amount of energy contained in 1 metric ton of crude oil; 1 ton of Fuelwood $=0.38$ TOE. (Naibbi 2013, p. 33). He further reiterated that while the developing countries derive less than $10 \%$ of their energy needs from fuelwood. Africa and the rest of the world make use of over $40 \%$ of energy needs from fuelwood.

The problem of fuelwood sourcing is rooted in the inability of the resource poor farmer to obtain fossil fuel derivatives such as kerosene, natural gas (Asifat2012, p . 23). The situation is further aggravated with the increase in price of fuel (crude petroleum prices). to meet their daily demand for cooking, heating and other domestic needs. This lead to the belief that an upsurge in the demand for fuel wood will triple and thus, lead to unsustainable and catastrophic exploitation of forest trees for fuel wood leading to environmental degradation (Cline-Cole and Maconachie, 2015, P. 17).

In another study, Asifat(2015) remarked fuelwood consumption for various purposes is causing serious deforestation problems in Nigeria leading to biodiversity loss further accentuating the environmental problem. (Salami, 2006).

Table 1 presents data on fuelwood benefits of respondents in the study area.

It can be seen from the table 1 that $90 \%$ in Jigawa southwest shows the highest degree derive benefits for energy sourcing through fuelwood. Jigawa northwest followed with $88 \%$ while the lowest percentage is that seen in Jigawa northeast $(81 \%)$. Many farmers own individual woodlots that are planted with the exotic Neem (Azadirachta indica) which in local Hausa dialect is called "Bedi". The study revealed that there were more woodlots planted close to farms located in the northwest than those found in both the southwestern and northeastern parts of the Jigawa state. This could be attributed to the additional gains the farmers claim to make in selling firewood(fuelwood) sourced from these woodlots to gain income and the ecological benefit of the lots serving as windbreaks there by providing protective cover for crops on farmlands. 


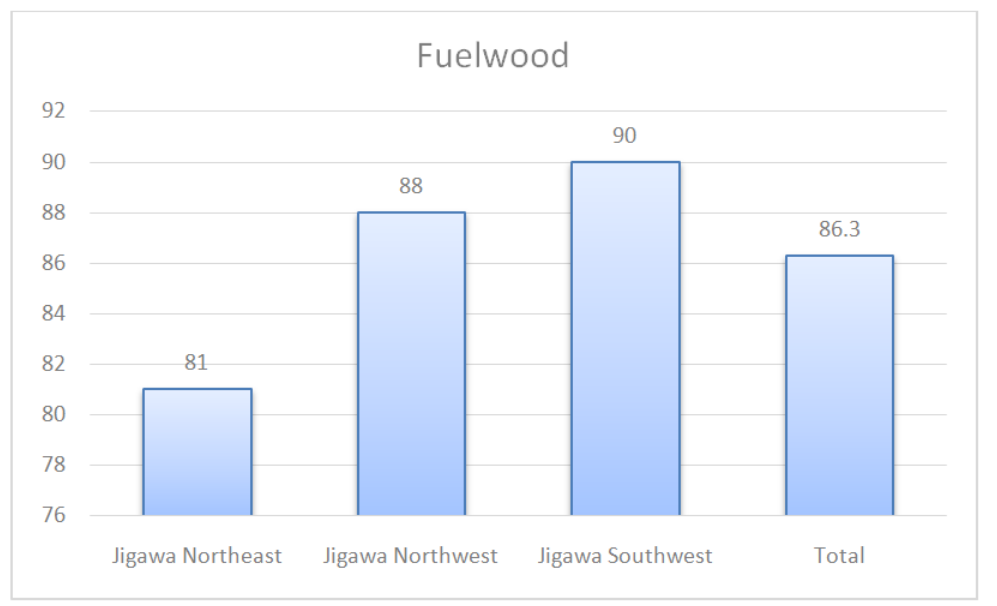

Figure 5: Fuelwood in the study area

\section{Soil Erosion Control}

One of the greatest threat to livelihood and environment of the farming community is erosion. In semiarid region, erosion due to water action i.e run off combines with wind erosion that is more pronounce due to the arid nature of the climate of Jigawa.

Among other agroforestry, practices Shelterbelts construction en masse started in the early 1980s in northern Nigeria. Arguably, a $14 \%$ increase in the yield of millet beside a Eucalyptus camaldulensis belt has been claimedin northern Nigeria (Ujah and Adeoye 1984). Also, Onyewotu (1996, p. 8) show in a study in Yambawa shelterbelts Dambatta, Kano, higher increase in yield of millet due to the effect of belts on wind flow dynamics. The primary function of these belts is wind erosion control. Other species of trees used as windbreak(shelterbelts are, Azadirachta indica(Neem), Anacardiumoccidentale, Khayasenegalenses,

Table 1 Depicts the responses of the erosion control benefits oe responses show that on the average $79 \%$ are positive that the influence of the practice is beneficial. $21 \%$ laid complaints that if only they were allowed to take total control of the management of these belts ,they could make optimum yield from them.

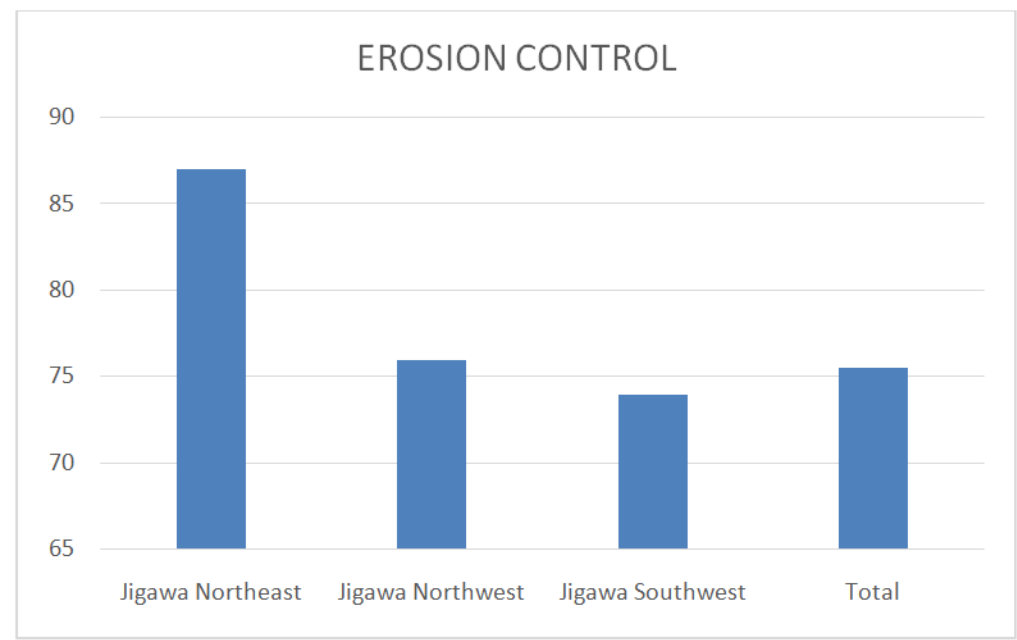

Figure 6: Benefits of Erosion control

Jigawa northwest elicited the highest response of $89 \%$. Several farmlands were seen in the northwestern Jigawa in Giwa LGA, Yankwashi to be cultivated within the strips of shelterbelts. In Yankwashi area, the belts were planted with the Eucalyptus camaldulensis (Eucalyptus tree). In local Hausa dialect, it is called "Turare". The belts in Gwiwa mostly were plantedwith Azadirachta indica (Neem). Jigawa northeast had a response of $76 \%$ and Jigawa southwest props up the rear with $74 \%$. Although some farmers complained, the trees tend to impact on their yield negatively when crops are planted very close to these trees; overall, the response was positive. Figure 6 shows the graphical representation of the benefits accrued to erosion control in the sampled area. 


\section{Provision Of Food / Medicine}

Medicinal plants (shrubs, trees) have been in use to cure ailments for centuries. The earliest evidence on record of traditional medicine use as remedy for ailments can be traced to the Egyptians, Indians, Chinese, as far back as 5000 years. Herbal remedies constitute only those traditional medicines, which primarily use medicinal plant preparations for therapy (Pal and Shukla 2003)

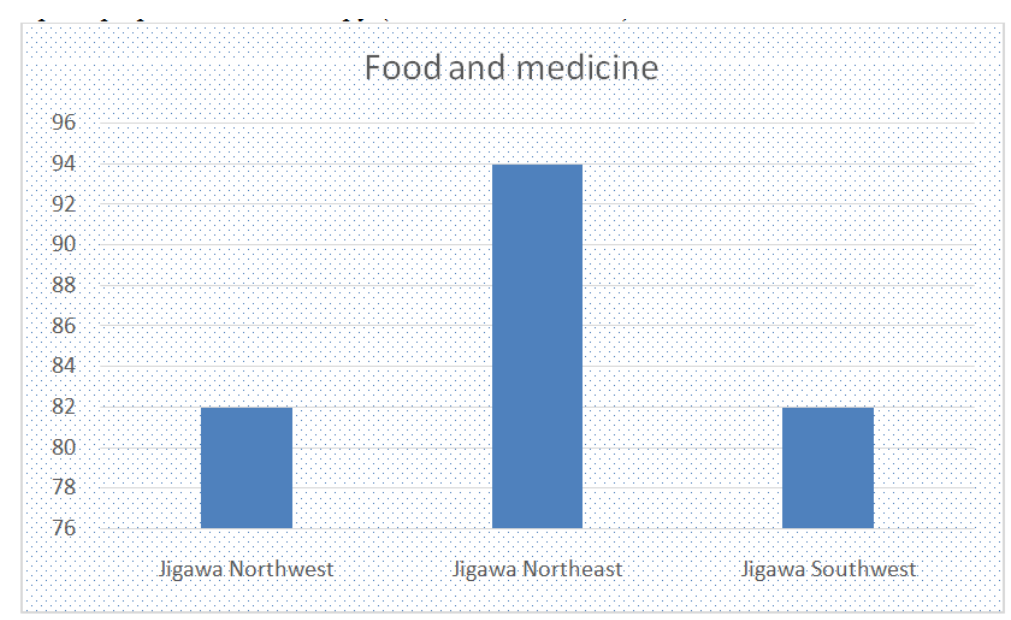

Figure 7: Medicinal Benefits

The farmers stated that the practice of agroforestry serves as a source of herbal cures and traditional medicines $(86 \%)$ on the average. Jigawa northeast has the highest respondents with benefits showing $94 \%$. Both Jigwa northwest and Jigawa southwest had $82 \%$ each in response to benefits deived.The increasing demands for medicinal plants by people in area causes several tree species to become endangered species. Trees identified by the farmer for their medicinal use include Adansoniadigitata(Baobab), Azadirachta indica (Neem) for curing fever,Malaria, Balaniteegyptiaca (Aduwa) for curing yellow fever and Menstrual cramp,Tamarindus Indica Tamarind tree tamarind tree used for preparation of insecticides mainly against malaria Infection.

\section{Conclusion}

The study revealed that farmers involved in the practice obtain several benefits. These include food and medicine, fodder and fuelwood and microclimate modification. It reveals environmental integrity can be sustained and possibly enhance the chances of attaining food security. However, on the down side there needs to be more enlightenment of the farmers to further take up the gauntlet and participate more of the practice in the area. Study revealed multipurpose trees likeCeiba petandra (silk cotton tree) and Anogeissus leiocarpus (African birch) is becoming extinct due to excessive extracting with no replacement.

\section{Recommendation}

In light of the findings of this work, the following recommendations are necessary

$>$ Collaboration on the part of Federal, state, Governments and NGO (non-governmental organizations) could enhance protection of indigenous trees that are over exploited in order to conserve them. The trees include Anogeissus leiocarpus(African Birch), ,Ficusglumosa (African rock fig), , Pericopsislexiflora, Bosewelliadalzielii (Frankinsence), Ceiba petandra(silk cotton tree) are fast becoming endangered.

$>$ Community heads need to be further involved in schemes that helps agricultural production as these community leaders have great authority over the farmers within their community

$>$ Establishment of tree seedling nurseries centers within accessible reach of the farmer could further encourage the adoption of the practice in the study are

\section{References}

[1] Abubakar. M.S. and Ahmad. D. (2010) Utilization of and Constraints on Animal Traction in Jigawa State, Nigeria. Australian Journal of Basic and Applied Sciences, 4(6): 1152-1156,

[2] Adedayo AG, Oluronke S. (2014) Farmers' Perception and Adoption of Agroforestry Practices in Osun State, Nigeria. Forest Res 3 : 127.

[3] Bhagwat S.A, Willis K.J, Birks HJB, Whittaker R.J (2008) Agroforestry: a refuge for tropical biodiversity? Trends in Ecology and Evolution 23: 261-264

[4] Biodiversity Journal, 4(3):427-434

[5] Charley and West, 1977, In Babalola (2009):Journal of Research in Forestry, Wildlife and Environment. Vol: 1 (1).

[6] Cline-Cole.R and Maconachie.R., (2015)Wood energy interventions and development in Kano, Nigeria: A longitudinal, 'situated' perspective Centre of West African Studies, Department of African Studies \& Anthropology School of History and Cultures University of Birmingham, UK 
[7] Dakata F. A. G. and Yelwa S A. (2012)An Assessment of mean and inter-seasonal variation during growing season across Kano region, Nigeria using normalized difference vegetation index derived from SPOT satellite data.

[8] David.O.O,.Jamala G. Y., (2013) Traditional Agroforestry Practice and Woody Conservation in derived Savanna ecosystem of Adamawa

[9] Ekwugha, U. E.(2016) Impacts of Agroforestry Technologies on Watershed Management in Imo State, Southeastern Nigeria Nigerian Journal of PHAgriculture, Food and Environment. Vol.12 (1):12-16

[10] Gold M, Garrett H (2009) Agroforestry nomenclature, concepts, and practices. In: Garrett HE (ed) North American agroforestry: an integrated science and practice. America Society of Agronomy, Madison, pp 45-56

[11] Hadejia .I, Smith. A (2017) Improving economic empowerment through the development of cluster farming initiatives in Jigawa State Paper presented at the "2017 World Bank Conference on Land and Poverty"The World Bank - Washington Dc.

[12] Jamala, G.Y., Tarimbuka, I. L, D. Moris and Mahai, S (2013) The Scope and Potentials of Fodder Trees and Shrubs in Agroforestry. Journal of Agriculture and Veterinary Science. Vol. 5, Issue 4

[13] Jose S (2009) Agroforestry for ecosystem services and environmental benefits: an overview. Agroforestry Systems 76: 1-10 .

[14] Leakey R, (1996). Definition of Agroforestry revisited. Agroforestry Today, Vol. 8, (1): 5 and 6.

[15] Mbow.C, (2014) Climate mitigation and adaptation through agroforestry Current Opinion in Environmental Sustainability, vol.6 :( 8-140)

[16] Naibi A.I., (2013) Fuelwood and Vegetation Change in Northern Nigeria: An Exploration Using Remote Sensing (RS), Geographical Information Systems (GIS) and Field Reports. Phd Thesis University of

[17] Nair P.K.R, M.R Rao, and L.E Buck, (2004). New Vistas in Agroforestry: A Compendium for the 1st World Congress of Agroforestry. Kluwer Academic Publishers, Dordrecht, the Netherlands.

[18] Nawaz .M.F,Gul S.,Farooq.T.H, Siddiqui MT, Asif.M, Ahmad N.K.Niazi (2016) Assessing the Actual Status and Farmer's Attitude towards Agroforestry in Chiniot, Pakistan International Journal of Biological, Biomolecular, Agricultural, Food and Biotechnological Engineering Vol.10, (8)

[19] NPC (2010) Nigeria population commission Report Abuja.

[20] Ogunbosoye, D. O and Babayemi, O. J (2010) Potential values of some non-leguminous browse plants as dry season feed for ruminants in Nigeria. African Journal of Biotechnology vol. 9 (18): 2720-2726

[21] Olofin and Tanko (2002) An overview of Physical and Human setting of Kano Region. Adamujoji publishers

[22] Olofin, E. A (1987). Some aspects of the physical geography of the Kano region and related human responses. Departmental Lecture Note Series: Geography Department, Bayero University. Debis Standard Printers, Kano, Nigeria.

[23] Onyewotu. L.o.z., Stigter. C.J., Oladipo. E.O. and Owonubi. J.J. (1996)

[24] Orimoogunje O.I., Asifat. J (2015) Fuel Wood Consumption and Species Degradation in Southwestern Nigeria: The Ecological Relevance.Journal of Landscape Ecology Vol. 8, (1)

[25] Richard. I, Michael .U, Felix E. O, and Isaac. O (2009) Pursuing Sustainable Development through Agroforestry in Nigeria: Geodemographic and Spatial Analyses of Agroforestry Implementation in 36 States and Federal Capital Territory, Journal of Sustainable Development in Africa Vol.11, (4)

[26] Richard. L. C., Munishi P. K. T. and Nzunda, (2013) Agroforestry as Adaptation Strategy under Climate Change in Mwanga District, Kilimanjaro, Tanzania, International Journal of Environmental Protection, vol. 3(11), pp. 29-38.

[27] Wireco P (2011) Farmers' Perception of Agroforestry Adoption in the Asunafo South District in the BrongAhafo Region of Ghana MSc graduate thesis studies, Kwame Nkrumah University of science and technology, Kumasi.

[28] Yields of millet between shelterbelts in semi-arid northern Nigeria, with a traditional and a scientific method of determining sowing date, and at two levels of organic manuring. TTMI-Project, Shelterbelt Research Station of the Forest Research Institute of Nigeria 